\title{
The Challenge of Academic Language
}

\section{Citation}

Snow, C. E., \& Uccelli, P. (2009). The challenge of academic language. In Olson, D. R., \& N. Torrance (Eds.), The Cambridge Handbook of Literacy (pp. 112-133). Cambridge: Cambridge University Press.

\section{Published Version}

doi:10.1017/CB09780511609664.008

\section{Permanent link}

http://nrs.harvard.edu/urn-3:HUL.InstRepos:11654980

\section{Terms of Use}

This article was downloaded from Harvard University's DASH repository, and is made available under the terms and conditions applicable to Other Posted Material, as set forth at http:// nrs.harvard.edu/urn-3:HUL.InstRepos:dash.current.terms-of-use\#LAA

\section{Share Your Story}

The Harvard community has made this article openly available.

Please share how this access benefits you. Submit a story.

Accessibility 


\section{CHAPTER 7}

\section{The Challenge of Academic Language}

\section{Catherine E. Snow and Paola Uccelli ${ }^{1}$}

Increasingly in recent years, educators have related worries about students' literacy accomplishments to their lack of "academic language skills" (August \& Shanahan, 2006; Halliday \& Martin, 1993; Pilgreen, 2006; Schleppegrell \& Colombi, 2002). Indeed, it seems clear that control over academic language is a requirement for success with challenging literacy tasks, such as reading textbooks or writing research papers and literature reviews. As early as the middleelementary grades, students are expected to learn new information from contentarea texts, so failure to understand the academic language of those texts can be a serious obstacle in their accessing information. Accountability assessments requiring written essays in persuasive or analytic genres are often graded using criteria that refer implicitly to academic-language forms. Even in the primary grades, students are expected in some classrooms to abide by rules for "accountable talk" (Michaels \& O'Connor, 2002 which specify features encompassed in the term academic language.

Despite the frequent invocations of "academic language" and the widespread con- cern about its inadequate development, there is no simple definition of what academic language is. What we consider "academic language" in this chapter is referred to in the literature using a variety of terms: the language of education (Halliday, 1994); the language of school, the language of schooling, the language that reflects school ing (Schleppegrell, 2001); advanced literacy (Colombi \& Schleppegrell, 2002); scientific language (Halliday \& Martin, 1993); or, more specifically, academic English (Bailey, 2007; Scarcella, 2003). As suggested by these terms, one approach to characterizing academic language is to resort to the contexts for its use - the language used in school, in writing, in public, in formal settings (see Table 7.1 for a more complete list). Thus, for example, Scarcella (2003) defines academic English as "a variety or register of English used in professional books and characterized by the linguistic features associated with academic disciplines" (p. 9). Similarly, Chamot and O'Malley (1994) identify it with school, defining it as "the language that is used by teachers and students for the purpose of acquiring new knowledge 
Table 7.1. Contextual Factors

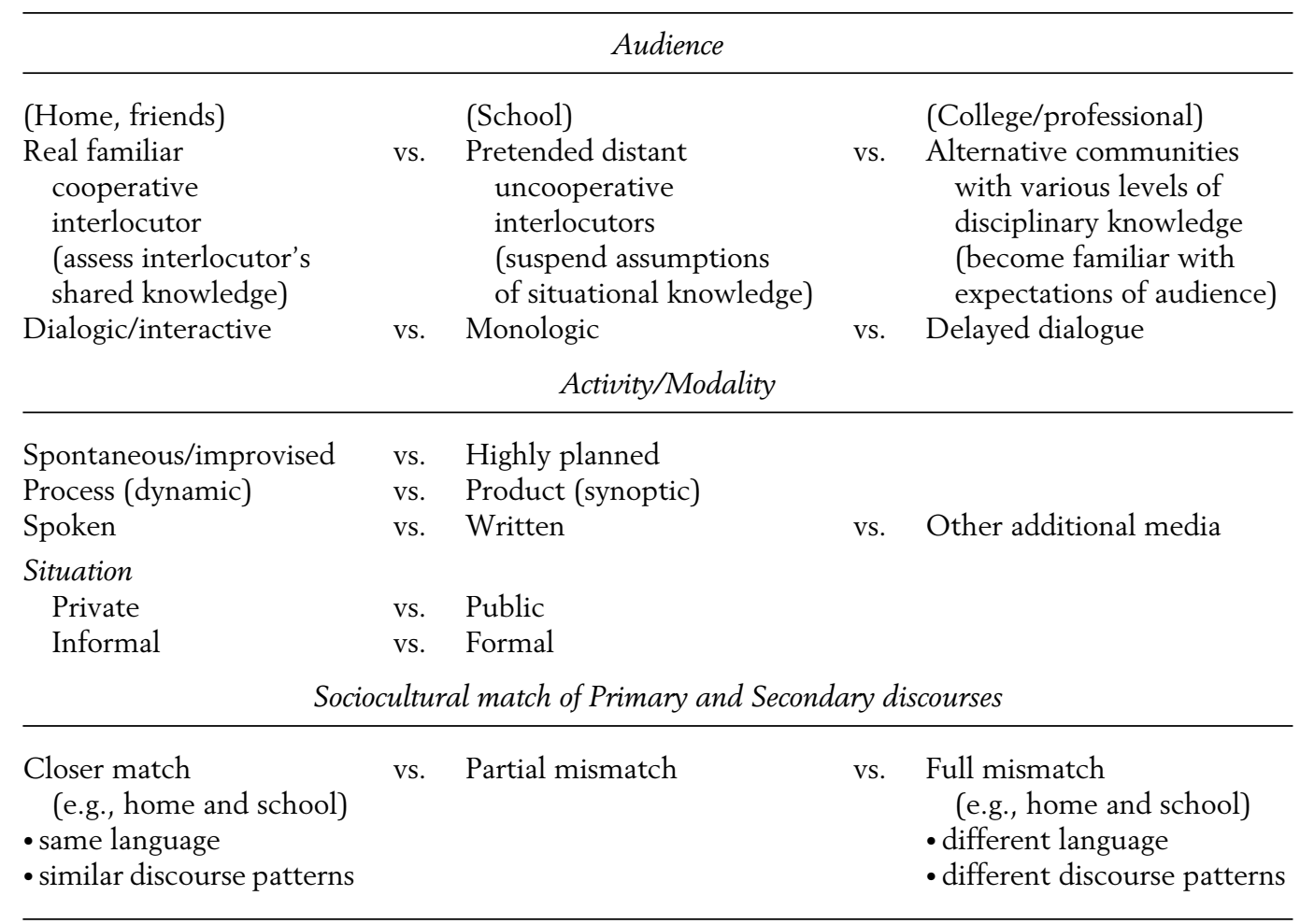

and skills...imparting new information, describing abstract ideas, and developing students' conceptual understanding" (p. 40).

Whereas identifying contexts of use and purposes is important, a comprehensive definition of academic language requires further specification. Scarcella (2003) identifies three dimensions required for academiclanguage proficiency: linguistic, cognitive, and sociocultural/psychological. Bailey defines being academically proficient as "knowing and being able to use general and content-specific vocabulary, specialized or complex grammatical structures, and multifarious language functions and discourse structures - all for the purpose of acquiring new knowledge and skills, interacting about a topic, or imparting information to others" (Bailey, 2007, pp. 10-11; in press).

Despite these advances in delineating academic language, a conceptualization of academic language within a consensual analytical framework that could guide educationally relevant research is still lacking.
Indeed, this topic, which seems as if it should be located in the exact center of educators' concerns, is notably absent from the table of contents in the most up-to-date handbook of educational linguistics (Spolsky \& Hult, 2007). Ironically, although academic language skills are widely cited as the obstacle to achievement for struggling readers in general, much of the empirical research on academic language has been done by those studying English Language Learners (ELLs). In other words, learning 'academic English' is recognized as a challenging task for second-language speakers of English, but the challenges faced by native speakers in learning the rules, the structures, and the content of academic English have received much less attention.

One line of thinking about academic language started with Cummins' proposed distinction between Cognitive Academic Language Proficiency (CALP) and Basic Interpersonal Communicative Skill (BICS) - a distinction he presented as 
relevant to second-language learners. In Cummins' original formulation of this distinction (Cummins, 1980, 1981), BICS was presented as easy and relatively automatically acquired, whereas acquiring CALP was seen as a lengthier process. Cummins was the first to point out cogently that many assessments of second-language proficiency focus exclusively on BICS yet are used to place students in classroom contexts where CALP is required for success (see Kieffer, Lesaux, \& Snow, 2008, for an updated version of this argument as it relates to the testing requirements of the U.S. No Child Left Behind Act). Although Cummins' work was crucial in raising awareness of the gulf between conversational and academic language, he did not specify in much detail which particular language skills were encompassed by CALP, in either his original discussions of it or later, somewhat more elaborated formulations (Cummins, 1984, 2001).

A more theory-based approach that has contributed centrally to our understanding of language, in general, and of academic language, in particular, is Systemic Functional Linguistics (SFL) (Halliday, 1994b). SFL studies language in its social context, understanding language as both shaping and resulting from social circumstances. Within this framework, linguists search for systematic relationships between the social context and linguistic features, including lexicogrammatical and discourse elements, in their analysis of the registers of particular genres. ${ }^{2}$ In studying academic language, Halliday (1993) emphasized its multidimensional and dynamic nature. On the one hand, he warned us that there is no single academic language, just as there is no single British English, but rather a number of varieties that share certain core features. On the other hand, Halliday highlighted that academic language is continually evolving as the sciences, disciplines, and subdisciplines themselves evolve. In fact, he argued that the evolution of science goes hand in hand with the evolution of scientific language, so that academic or scientific languages are not arbitrary sets of conventions but rather grammatical resources that make scientific thought possible.

Although SFL has proven to be highly relevant in studying the language of school (Schleppegrell, 2001), it is a linguistically sophisticated model originally designed more as a theory of language than as a framework for educational research. An educationally relevant framework would direct less attention to the description of linguistic features per se and more to the skills required in the process of mastering academic language and, thus, potentially to the nature of instruction that would promote those skills. In other words, we argue for the value of practice-embedded approaches to thinking about academic language that would generate more directly useable information. For example, Bailey (2007) derived valuable data about academic-language demands on ELLs from an analysis of content standards, classroom discourse, and the tests they are expected to pass. Scarcella (2003) and Schleppegrell (2001) also adumbrated the nature of academic language by describing the typical failures of ELLs who have advanced conversational skills but who struggle with high school or university writing tasks and by proposing instructional approaches to improving the academic-language skills of ELL students in tertiary-education settings.

Although the problem of academic language may be particularly visible or acute for second-language speakers, in fact, we argue that academic language is intrinsically more difficult than other language registers and that thinking about the educational experiences that promote its development is a crucial task for educators of all students. Furthermore, formulating instructional approaches to academic language is necessary not just for achievement in the domains traditionally associated with language (e.g., literature study, English language arts) but also for achievement in math, science, and other areas where allpurpose academic language forms the core of content-area-specific language. Designing instruction for academic and disciplinespecific language, however, requires having 
a convergent view of what academic language involves, how it should be conceptualized, where its boundaries are, and how it might be assessed.

Certainly, members of the academy can identify violations of academic language in our students' writing and may have learned something about the features of academic language by working hard to stamp them out in writings meant to communicate with practitioners or the general public. Despite these practice-based sources of knowledge about academic language, the central concept remains somewhat inchoate and underspecified. In the absence of a conceptual framework, it is difficult to design instruction to promote academic language, to properly assess academic-language skills, or to understand what normal, expectable progress toward achievement of academiclanguage skills might look like.

The goal of this chapter is to survey the work on academic language in order to provide an overview of its features as a basis for proposing a pragmatics-based framework that accommodates those many discrete features in a coherent model of communication. Based on this pragmatic framework, we then propose a research agenda focusing on issues that would take our understanding of this important topic a step farther. Given the absence of an agreed-upon set of criteria for academic language, we start by presenting an example of middle-school student writing to illustrate the rules of academic language. We then turn to a more formal inventory, based on theorizing about the differences between oral and written language, between informal and formal language, and between narrative and expository language, because these three distinctions overlap with and contribute to a sharpening of the definition of academic language. It is notable that academic language, unlike the categories of written, formal, and expository language, has no clear opposite. We start, then, from the assumption that language can be more or less academic - that is, furnished with fewer or more of the traits that are typical of academic language; we have no basis for postulating a separate category of lan- guage that has passed some threshold qualifying it as academic.

\section{Academic Language in Use: Some Examples}

The example we analyze herein was an endof-week paragraph produced by a middleschool student participating in the pilot implementation of a program intended to promote knowledge of all-purpose 'academic' vocabulary in particular and use of academic language more generally. The program was designed for use in an urban district in which assessment had suggested that students' reading comprehension challenges might be related to vocabulary limitations. Classroom observations in this district also showed that the vocabulary instruction that occurred was primarily focused on disciplinary terms (e.g., sonnet, legislation, digestion, and rhomboid in English language arts, social studies, science, and math, respectively), whereas pretesting showed that a significant proportion of the students was struggling with the more all-purpose vocabulary found in their texts, including words like dramatic, interpret, sufficient, and decade.

The program consisted of week-long units in each of which five 'academic vocabulary' words were targeted. The five target words (and other words of similarly low frequency) were introduced in the context of a paragraph about a topic selected to be engaging to young adolescents and to be somewhat open-ended (i.e., supporting a number of different plausible points of view). The introductory paragraphs were written in a style that might be characterized as 'serious journalistic' and each briefly presented two or more positions on the topic of the week, with limited elaboration of each position. The instructional program presented focused teaching about the target words (i.e., their varying meanings in different contexts, morphological analyses, and variants of them) as well as contexts for the students to use the words. Thus, some form of debate about the issue in the paragraph was recommended for social studies class 
and "taking a stand," a short argumentative essay in which each student was asked to develop and justify his or her opinion about the topic of the week, was the standard Friday activity.

It is important to note that these "taking a stand" paragraphs were written in 10 to 15 minutes, were not preceded by explicit instruction in how to construct them, and were not graded. Thus, we can assume that they reflect something of the students' natural and unedited writing style, with the exception that students were encouraged to use the words of the week if possible; complying with this request sometimes led to awkward constructions or even outright errors.

EXAMPLE 1: Female Seventh-Grader (12/08/06), responding to the prompt: What do you think the function of school is?

What's the purpose of school you tell me! Well first of all, school is to get your education. [S]o we can learn what the teachers learn[,] so we can be ready for the 8th grade. Because if we don't get [an] education[,] you can't be what you want to be when [you] grow up.

Secondly to get us ready so we can make it to the 8 th grade ready and prepared[.] [T] hey don't want to send [us] to the 8th grade because they like us or the[y] just feel sorry for us. No! [T]hat's not the reason[.] [T] hey want to prepare [us,] make sure we understand the work. When we grow up we also want to get a good job because we are the future leaders of the world. That's [why] we need to work with the function of the school[,] so you [can] show us [how] the world should be.

As a piece of writing from a seventhgrader, this falls short of excellence on many grounds. First, it is inconsistent in attention to conventions like capitalization, punctuation, and spelling (corrections introduced for readability are indicated in square brackets). Second, the major position expressed (i.e., we go to school to get a good job, to be what we want to be when we grow up) is somewhat obscured by other claims (i.e., attending school is necessary for promotion to higher grades, teachers will not promote students out of pity, teachers want students to learn) whose relationship to the central claim is left unclear. These issues of form and content are rightly important in judging this as a piece of writing, but our focus in this chapter is how we respond to it as a piece of academic language. The key question is: What is the most effective pedagogical response to writings like this? Will academic language follow naturally if students are helped to formulate their ideas more fully and precisely, or should one teach the academic forms using the content the students themselves have generated? If we agree that revision and rewriting help to improve the quality of writing (Klein \& Olson, 2001), then what would be the best strategies to scaffold effective revision and rewriting geared toward improving academic-language skills more broadly?

Consider Example 1a, a rewritten version of the previous example paragraph that attempts to express the same ideas in a more academic form.

EXAMPLE 1A.

What is the purpose of school?

First, school functions to provide an education, so students can learn what the teachers know and be prepared to continue their education at higher levels. Teachers will not promote students who 
have not learned the material, so understanding the work is very important. Without an education, attaining one's career goals is very difficult.

Second, getting a good job is dependent on going to school. Today's students are the future leaders of the world. School could help them understand how the world should be.

Analyzing the differences between Examples 1 and ra reveals some of the key features of academic language. Example ra eliminates markers of involvement (e.g., you tell me! No!); removes redundancy (the point about getting ready for eighth grade is made twice in Example 1, only once in Example 1a); moves from specific and personal to generic formulations of claims (eighth grade becomes education at higher levels; they don't want to send us... becomes teachers will not promote...); substitutes metadiscourse markers (first, second) for more colloquial expressions (well first of all); compresses Example 1 clauses into adverbial phrases (without an education) and nominalizations (getting a good job); and imposes a consistent, distant, third-person perspective, whereas Example 1 shifts between first- and second-person perspectives. Although more academic in style, Example ra is still not a particularly good response to the topic assigned because it is restricted to the same ideas presented in more or less the same order as Example 1.

The paragraphs written by the middlegrade students participating in this program were not devoid of academic-language features. Some students provided overarching initial or concluding statements, used metadiscourse markers, and incorporated the academic vocabulary they were taught. Nonetheless, the paragraphs, particularly in contrast to the more academic translations one could provide for them, displayed language features inappropriate for academic language (e.g., colloquial expressions, involvement markers, redundancy) and revealed characteristics of academic language that the students did not employ (e.g., grammatical compression, generic statements, impersonal stance, a variety of connectives).
Finally, comparing the student taking-astand paragraph to the original paragraph designed to stimulate thinking about this topic reveals still more academic-language features.

EXAMPLE 1B. Paragraph prompt.

What is the purpose of school?

Why do we go to school? One prime goal of education is to transmit knowledge. Another is to enhance students' capacities to earn a good living. Some would argue that schools should orient students toward a set of shared values, in order to facilitate the maintenance of a democratic state. Others contend that schools should help students develop an understanding of the perspectives of others, to promote social harmony. Still others think schools should teach students to challenge authority, reject received opinion, and think for themselves. Of course, if we accept this last version of what schools should do, then we will have to expect that the curriculum will be massively adjusted and classroom activities radically altered. Whereas thinking for themselves is something educators value, students don't always have the license to do so in the classroom.

This adult-written paragraph reveals a number of features not present in the student paragraphs, as follows:

- lexical density

- modal verbs

- endophoric reference

- abstract entity as agent (school)

- wide variety of connectives

- stepwise logical argumentation

- evidence of planning

- detached stance

- authoritative stance

- lots of abstract/low-frequency vocabulary

- elaborate noun phrases (nominalization)

- markers of course of rationale

- deductive/inductive inference

Some of these features, such as the high density of relatively low-frequency words, were deliberately introduced into the paragraph to serve the purposes of the program. Others were required by the argumentative genre; these included the logical progression of the argument and the explicit marking of different points of view. Other features, 
such as the use of nominalization, were a product of efforts to keep the paragraph brief. Others, such as the authoritative and detached stance, are simply the default academic writing style.

\section{Academic Language: An Inventory of Features}

Having explored examples of academic language and its absence in actual practice, we now must confront the issue of how to conceptualize 'academic language.' A first advantage of a coherent characterization of academic language might be the value of sharing it with struggling students. Schleppegrell (2001) argues that only rarely are the linguistic expectations of schoolbased tasks made explicit to students, despite the fact that students' academic performance is judged considering these expectations. Without explicit discussion of linguistic expectations, academic language constitutes an arcane challenge for many, and some explicit teaching about it might be useful.

Linguists and educational researchers have revealed features about which students might be taught through contrastive analysis of language corpora (e.g., Biber \& Reppen, 2002; Chafe \& Danielewicz, 1987), evolutionary analysis of scientific language (Halliday \& Martin, 1993), explorations of performances at different levels of expertise (Schleppegrell, 2001), in different academic disciplines (Achugar \& Schleppegrell, 2005; Schleppegrell, 2007), and in specific genres (Halliday \& Martin, 1993; Swales, 1990). Table 7.2 represents an effort to summarize this literature, by organizing the many linguistic features identified under the domains of knowledge involved in academic language in a way that makes them somewhat more tractable. 3 The features listed to the left are more characteristic of colloquial language, whereas the features toward the right are more typical of academic language. Linguistic features are divided into those referring to interpersonal stance, information load, organization of information, lexical choices, and representational congruence (i.e., how grammar is used to depict reality). Of course, the realization of all these features requires knowledge of specific vocabulary and grammatical structures. In addition to these linguistic skills, three core domains of cognitive accomplishment involved in academic-language performance are genre mastery, command of reasoning/argumentative strategies, and disciplinary knowledge.

The typical interpersonal stance expected in academic language is detached and authoritative. As we saw in Example 1, you tell me! and No! are markers of an involved style that in Schleppegrell's words form part of a "hortatory style that instantiates a context of interaction" (2001, p. 446). In contrast, academic language requires a nondialogical and distant construction of opinion, as well as "an assertive author [or speaker] who presents him/herself as a knowledgeable expert providing objective information" (Schleppegrell, 2001, pp. 444-445) (for an illustration of detached versus involved writing styles, see Schleppegrell, 2001, p. 445).

The information load in academic discourse is characterized by conciseness and density. Academic writing or speech is expected to be short and to the point, conveying information without unjustified repetitions. In Example 1, the repetition of being ready for 8th grade stands out as a violation to the flow of information expected in such a piece of writing. In contrast to the typical redundancy of spontaneous speech (Ong, 1982/1995), conciseness is highly valued, with only the minor exceptions of artful pseudo-redundant moves such as those included in abstracts or summaries and conclusions. Besides, academic language packs a lot of information into a few words. This informational density is evident in the high proportion of content words, usually achieved through nominalizations and expanded noun phrases (Chafe \& Danielewicz , 1987; Halliday \& Martin, 1993; Schleppegrell, 2001).

At the syntactic level of organization of information, Halliday (1994b) subdivided the 
Table 7.2. Linguistic Features and Core Domains of Cognitive Accomplishments Involved in Academic Language Performance

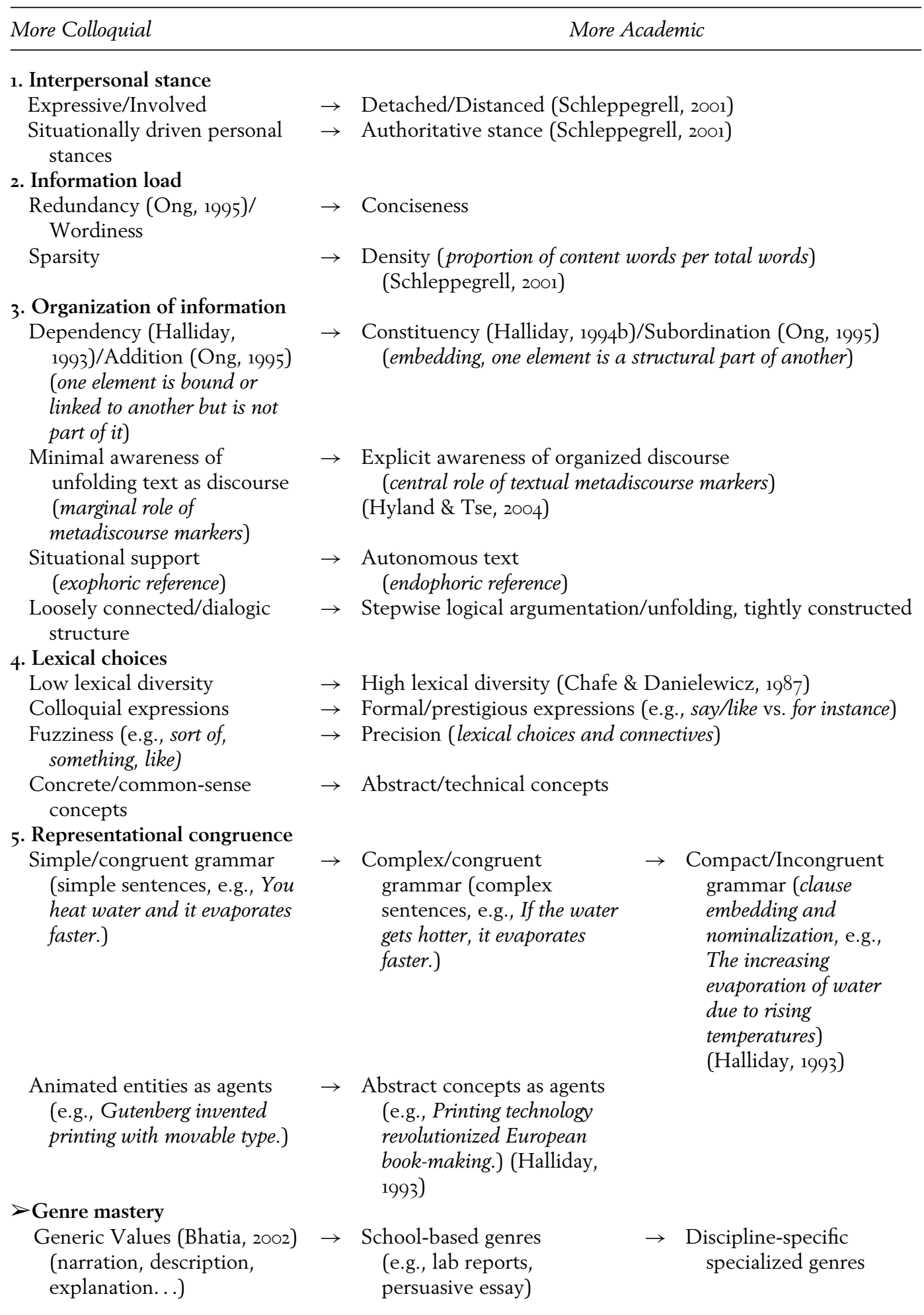


Table 7.2 (continued)

\begin{tabular}{|c|c|c|c|c|}
\hline More Colloquial & & \multicolumn{3}{|c|}{ More Academic } \\
\hline \multicolumn{5}{|l|}{$>$ Reasoning strategies } \\
\hline $\begin{array}{l}\text { Basic ways of argumentation } \\
\text { and persuasion }\end{array}$ & $\rightarrow$ & $\begin{array}{l}\text { Specific reasoning moves } \\
\text { valued at school } \\
\text { (Reznitskaya et al., 2001) }\end{array}$ & $\rightarrow$ & $\begin{array}{l}\text { Discipline-specific } \\
\text { reasoning moves }\end{array}$ \\
\hline \multicolumn{5}{|l|}{$\begin{array}{l}\text { Disciplinary knowledge } \\
\text { - Taxonomies }\end{array}$} \\
\hline Commonsense understanding & $\rightarrow$ & $\begin{array}{l}\text { Abstract groupings and } \\
\text { relations }\end{array}$ & $\rightarrow$ & $\begin{array}{c}\text { Disciplinary taxonomies } \\
\text { and salient relations }\end{array}$ \\
\hline \multicolumn{5}{|l|}{ - Epistemological assumptions } \\
\hline Knowledge as fact & $\rightarrow$ & Knowledge as constructed & & \\
\hline
\end{tabular}

traditional category of subordinated clauses into "hypotactic" and "embedded" clauses. Hypotactic clauses are subordinated clauses that are dependent on but not constitutive of other clauses, such as adverbial clauses or those introduced by verbs of saying or thinking (Colombi, 2002). In the following example, clause $a$ and clause $b$ are hypotactic clauses: I concluded [that the party was a total failure $]_{a}$ [because it ended before midnight $]_{b}$. In contrast, embedded clauses form part of another clause, such as clause $a$ and clause $b$ in the following sentence: The party [which ended before midnight $]_{a}$ was a total failure [that we hope will not be repeated] $]_{b}$. Whereas some posit that addition and coordination are characteristic features of colloquial language that contrast with subordination and complex syntax (Ong, 1982/1995), Halliday (1994b) persuasively argued that the crucial distinction is dependency (which includes hypotactic subordinated clauses) versus constituency (embeddedness). He argued that embedding is a distinctive feature of scientific or academic discourse. If we contrast the subordinated clauses in Examples 1 and $1 b$, it becomes evident that embedded clauses are used only in the latter text.

Organization of information also involves explicit marking of text structures. Explicit awareness of text structure is indexed via discourse and metadiscourse markers that have been widely explored in the literature.
In Hyland and Tse's (2004) words: "metadiscourse represents the writer's awareness of the unfolding text as discourse: how writers situate their language use to include a text, a writer, and a reader" (p. 167). These authors developed a taxonomy of metadiscourse markers and their functions by studying different types of texts. Additionally, information in academic language needs to be organized according to a stepwise logical argument structure that makes sophisticated use of autonomous endophoric reference strategies instead of relying on situational context or underspecified references.

At the lexical level, a diverse, precise, and formal repertoire that includes appropriate cross-discipline and discipline-specific terms is desirable.

The final level concerns representational congruence, or the correspondence between language and the reality it represents. The concept of grammatical metaphor plays a central role in Halliday's model. According to Halliday (1994a), in children's commonsense language, nouns refer to things, verbs refer to processes, adjectives denote attributes, and connectives establish relationships. However, when these grammatical categories are extended beyond their prototypes (e.g., when nouns refer to processes like evaporation or verbs refer to relationships like precede), a grammatical metaphor, which Halliday calls a compact and incongruent form, is created. He argued 
that experience is reconstructed when nominalized forms such as evaporation are used; this term has the semantic features both of processes (water evaporates) and of things (because a noun prototypically refers to things). In Halliday's terms, these processes have been transformed metaphorically into virtual objects, "[ $t]$ he effect of this is to provide a less dynamic, more synoptic vision of the world, in which reality is as it were held still, rendered fixed, bounded and determinate, so that it can be observed, measured and, if possible, explained" (Halliday, 1994a, p. 14). Halliday emphasized that there would be no noticeable effect of sporadic uses like that but that academic language is profusely populated by these grammatical metaphors (in particular, nominalizations of processes).

Nominalization also creates lexical density. The recursive linguistic principle permits nominalizations to function as embedded clauses of other propositions, allowing long, information-packed sentences. Furthermore, in examples like The increasing evaporation of water due to rising temperatures is alarming, not only is the nominalization phrase the subject of a longer sentence, but it also constructs the claim of relationship between rising temperature and evaporation as assumed truth rather than a falsifiable claim, contributing to the authoritative stance previously discussed.

However, grammatical metaphor is not the only case of representational incongruence. Another incongruent move of academic language involves using abstract concepts as agents. Whereas in colloquial interactions, animate entities are typically the grammatical agents of sentences, academic language often displays abstract concepts as agentive subjects of sentences. For example, in Gutenberg invented printing with movable type, a noun that refers to a person is the subject and agent of the sentence. However, the sentence, Printing technology revolutionized European book-making, presents a noun that refers to an abstract concept as agent, a less intuitive construction that departs from our commonsense knowledge of the world (Halliday \& Martin, 1993).
Finally, all these linguistic features must be coordinated with at least three additional cognitive accomplishments: genre mastery (Bhatia, 2002; Swales, 1990); command of reasoning/argumentative strategies (Reznitskaya, Anderson, Nurlen, Nguyen-Jahiel, Archodidou, \& Kim, 2001); and disciplinary knowledge (Achugar \& Schleppegrell, 2005; Wignell, Martin, \& Eggins, 1993). As students advance in their mastery of these three domains of knowledge, they learn to put features of academic language at the service of genre conventions, persuasive and clear argumentations, and disciplinaryspecific relationships and concepts. These are three vast areas of research, which have been the focus of work in fields such as English for Specific Purposes, the "Sydney school" of genre theory, and the Collaborative Reasoning approach, among others. Reviewing these three areas with the detail they deserve would go beyond the scope of this chapter.

As we have seen herein, the claims that have been made in the literature about the characteristics of academic language result in a lengthy list of features. The mere length of the list in Table 7.2 displays the problem with our current conception of academic language: dozens of traits have been identified that contrast with primary or colloquial language and that might function as markers of academic language, but it is unclear that any of them actually defines the phenomenon. Any of these traits might be present in casual spoken language: Is it their co-occurrence that defines some language as academic? Is it their frequency? How, if at all, do these various traits relate to one another? Are some particularly crucial and others merely epiphenomena? Are some causes and others consequences? How does the list in Table 7.2 help us with the tasks of assessment or instruction?

\section{A Pragmatics-Based Approach to Academic Language}

The problem with the inventorizing approach reflected in Table 7.2 is the omission 


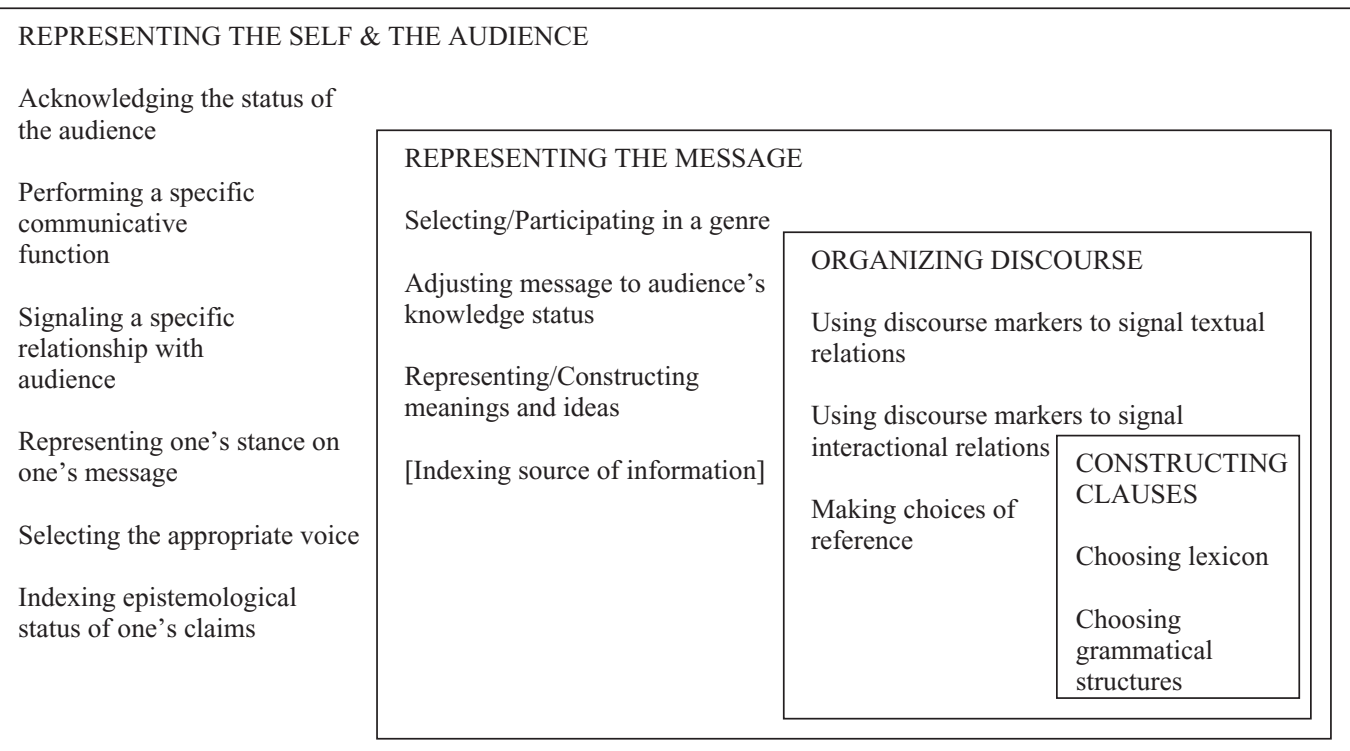

Figure 7.1. Nested challenges within any communicative event.

of attention to the overall rationale for these features of academic language. In other words, we start from the assumption that language forms represent conventionalized solutions to communicative challenges and that decisions about specific forms constitute solutions to those challenges. What are the communicative challenges to which the features of academic language are meant to respond?

In Figures 7.1 and 7.2 , we present a first attempt to answer this question (and, in the process, questions about how the traits listed in Table 7.2 relate to one another). Figure 7.1 represents a view of language in which communicative goals are seen as driving decisions about specifics of expression. In this view, all communicative forms are a simultaneous solution to two tasks: representing the self and representing the message. Representing the self involves selecting (or perhaps simply having) a voice and a relationship to the audience; representing the message requires conceptualizing some thought and figuring out what the audience already knows and needs to know about it.

Given a representation of self and message, then discourse and utterance features consistent with those prior frames are realized.
In many communicative exchanges, selfrepresentation is fairly straightforward (e.g., self as purchaser of a kilo of onions, self as student in a first-grade classroom) and the message is relatively uncomplicated (e.g., How much do the Vidalia onions cost? 3 plus 2 equals 5 ). The rules governing discourse structure, lexical selection, and grammatical formulation for such exchanges are accordingly relatively easy to learn and to implement. Furthermore, formulating some frequently occurring but potentially challenging messages has been greatly simplified by the availability of conventional forms designed to express them (e.g., greetings, requests, apologies, condolences).

We argue, however, that characteristics of academic language represent an accommodation to the two ubiquitous features of communicative tasks - representation of self and of one's message - under particularly challenging conditions (see Figure 7.2).

The first condition is the need to formulate messages that are relatively challenging on any number of grounds - for example, because the content is inherently complicated, because some of the concepts being talked about are abstract or theoretical, because some of the claims being made have an uncertain epistemological status, and so 


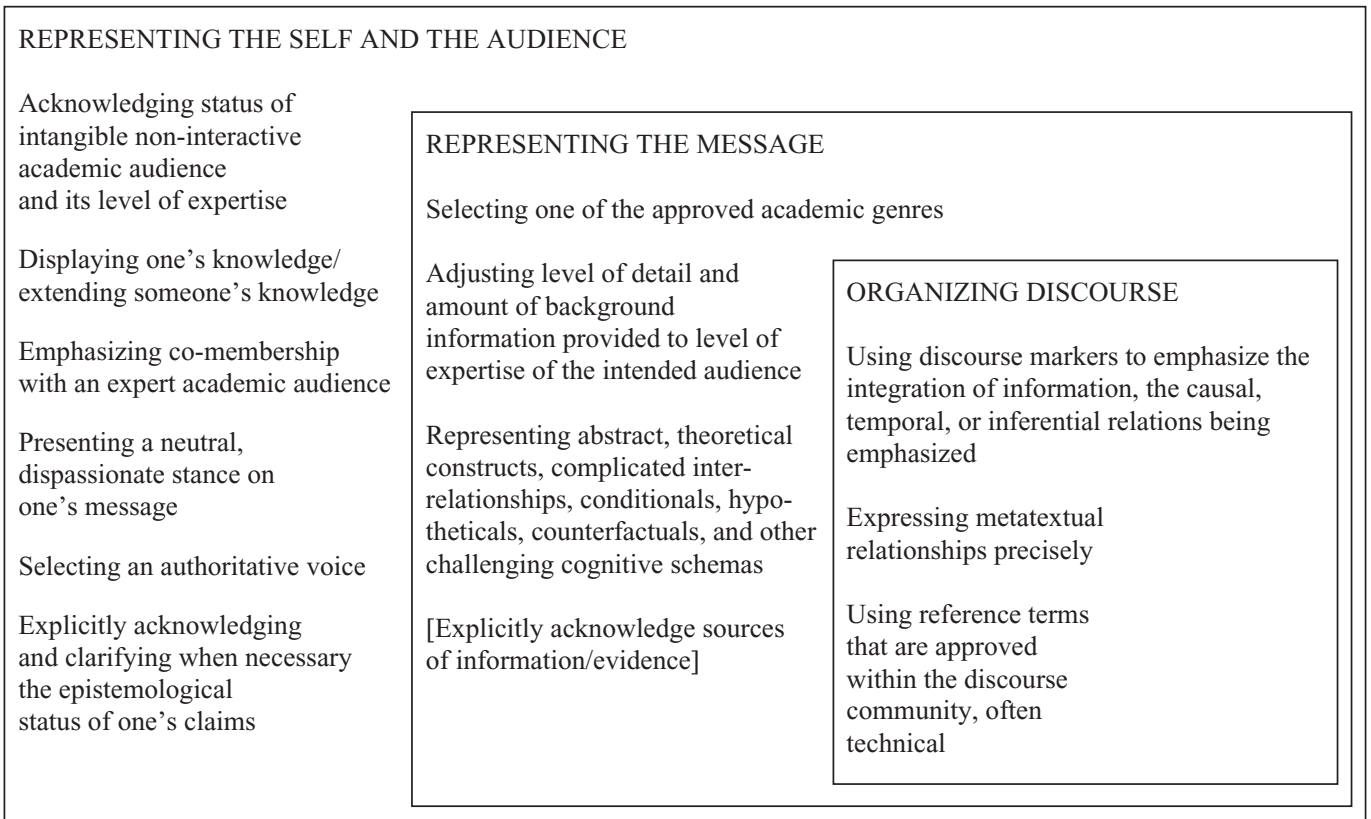

Figure 7.2. Nested challenges within a communicative event calling for academic language.

on. It is simply more difficult to explain the process by which cells replicate, or the theory of evolution, or the various factors contributing to global warming than it is to negotiate the purchase of onions or respond to an addition problem; therefore, the language required must be more complicated. 4

The second challenge is to identify the audience and the appropriate relationship between self and audience. An early developmental task is to assess the listener's knowledge so as to provide sufficient information and to gradually free language from situational support. The additional communicative challenges of academic language require learning the traditions that govern discourse among participants in an intangible academic community. The questions of who the audience is and what they know are crucial in appropriately framing the discourse in academic tasks, yet they are not always easy to unravel for students. In face-to-face interactions, speakers learn language by identifying co-occurrences between language forms and situational context via repeated participation in similar speech events with clearly identifiable participants. In those situations, children ini- tially rely on contextual support (e.g., pointing, enactment, gestures, deictics), but they gradually learn to use language as its own context. Of course, autonomous discourse skills develop throughout the school years and are needed in many nonacademic situations as well (e.g., talking on the telephone, telling a story, writing a letter to a friend). From a communicative perspective, what seems to make academic language particularly challenging, in addition to the complexity of the message, is that the components of the communicative situation are less obvious and less accessible. In the academic-discourse world, identifying patterns of co-occurrences between specific situations and linguistic forms is a much harder task. Approaches to this task taken by inexperienced users of academic language range from borrowing oral-language forms 5 to imitating experts' discourse so slavishly as to verge on plagiarism.

Moreover, the producers of academic language need to establish their own level of authoritativeness and negotiate their relationship with a distant and potentially critical or incredulous audience, through the language forms chosen. Impersonal, generic, 
and distancing forms are required because even if a personal relationship between the producer of academic language and the audience does exist, that relationship is irrelevant to the self being represented under conditions that call for academic language. Thus, the intrusion of spokenlanguage involvement markers in Example 1 represents a violation of academic-language norms because involvement with the audience is inappropriate under those circumstances. Control over modals and explicit markers of epistemological status (e.g., probably, likely, undoubtedly, evidently, obviously) represents acknowledgment of the need to be explicit about the credibility of one's claims. That need derives partly from the obligation to represent the message accurately and partly from the protection of personal authority that comes from making reasoned and modulated claims.

Thus, the challenge lies not only in the audience's physical absence but also more profoundly in the somewhat indeterminate nature of this audience. Figure 7.2 describes the audience as an "intangible noninteractive academic audience." At school, even though teachers are the ones who request assignments, students need to suspend their personal relationship with their teacher and ignore what they know their teacher knows in responding. Instead, they need to imagine a nonfamiliar audience with high levels of language but without specific knowledge of the target topic.

In line with the pragmatics-based model proposed herein, we think that two essential starting points for students are to (1) gain an awareness of the desired relationship among participants in academic communications; and ( 2 ) understand that meaning resides not only in what they say but also in how they communicate it. We are arguing, then, that the long list of academiclanguage markers reviewed in Table 7.2 can be sorted out usefully by fitting the various items into this pragmatics-based understanding of academic language. Forms that have to do with the largest task self-representation - are those that express authoritativeness, that perform the function of displaying knowledge to or for someone, that acknowledge co-membership with the audience, that express the speaker's unique voice within the 'academic community,' and that make explicit the epistemological assumptions under which the speaker is operating. Those markers, then, must be integrated with language forms imposed by an adequate representation of the message to be conveyed, which in turn leads to decisions about genre (in the broadest sense), about the audience's level of background knowledge to be presupposed and the level of detail to be included, about the mechanisms for making reference to key concepts and interrelationships, and about the need to acknowledge sources of information. Having established what self and what information will be represented, then text-specific decisions at the level of discourse organization (e.g., How will the organizational structure of the discourse be signaled? How will relationships of temporality, causality, dependency, conditionality, and so forth be talked about? How much anaphoric and exophoric reference is permissible?) and clause constructions can be made.

Figures 7.1 and 7.2 present a relatively simplistic view of the nested relationships among these different levels; clearly, much more work would need to be done to specify implications of a specific decision at any of the levels for decisions at lower or higher levels. Nonetheless, we hope that this representation makes clear that the clause- or discourse-level characteristics typical of academic language may occur under other circumstances, but that the most likely conditions for them are in satisfying the demands that are particular to self-representing as a member of the 'academic-language-using community' and that are imposed by the need to express complex content in efficient and effective ways.

\section{Academic Language: A Research Agenda}

The view presented herein makes no clear predictions about the order of development 
of the various academic-language markers or about an optimal approach to teaching academic language. Indeed, these are issues we would prioritize in a research agenda focused on academic language. Clearly, children start acquiring clause-level skills as soon as they learn to talk; the challenge for teachers is to figure out precisely how the construction of clauses needs to be adapted to contexts in which academic language must be produced and/or comprehended and what new lexical and grammatical knowledge is needed to succeed in those contexts. Similarly, children produce extended discourses from early in their language-acquisition trajectories, and they use in conversational narratives some features that may also be relevant to academiclanguage texts. So, the specific task of becoming skilled in academic language requires expanding the repertoires available at those two levels for use in nonacademic contexts.

As can be inferred from the model presented herein, the skills required for successful academic-language performance go beyond the traditionally cited lexicogrammatical skills to include a level of metacommunication. For instance, research with Hebrew-speaking children and adults has shown that whereas knowledge of formal sophisticated morphology and syntax increases from age five to age seven, only college-educated adults and some older adolescents are capable of appropriately displaying this knowledge in the construction of texts (Ravid \& Tolchinsky, 2002). As stated by Berman (2004) and by Ravid and Tolchinsky (2002), a crucial aspect of later language development, in addition to vocabulary expansion, is learning a variety of sophisticated morpho-syntactic structures and how to use them flexibly for diverse communicative purposes.

We propose, then, two large categories of urgent research questions. One set has to do with the developmental course of academic language and includes attention to issues such as the following: What does normative development look like? How does it relate to literacy development? Which early- developing language skills constitute precursors to later academic language? How do the various components of academic language relate to one another? The second set has to do with instruction - for example: What are effective methods for promoting academic language? Which aspects of the system need explicit instruction and which do not? How can we best embed (or not) academic-language instruction into attention to literacy instruction and contentarea learning?

We expand briefly on the research base for these two sets of questions in the following sections.

\section{The Developmental Course and Composition of Academic-Language Skills}

\section{What Are the Early Precursors?}

Even though the field of academic language is concerned mostly with the study of later language development, it is of crucial importance to recognize that academic-language skills fall on a continuum with earlier language skills. Within this view, exploring earlier language skills that might predict academic-language skills later in life is of particular educational relevance. Specifically, we need research to explore which skills are predictive of later mastery of academic language and, in turn, which contexts are most conducive to efficient learning of academic-language skills.

Reviewing relevant literature, BlumKulka (in press) documents preschool children's early development in the areas of conversation and extended discourse, including what she calls literate discourse. Blum-Kulka defines literate discourse as "include[ing] all those uses of language that involve elements of planning, precision, distancing, internal coherence, and explicitness. It may appear in discursive events that mainly require the skills for constructing a continuous text, such as public lecture or written articles, as well as when the main requirement is conversational skills ... especially on topics that are remote from the here-and-now" (p. q). 
Within conversational skills, Blum-Kulka includes thematic coherence, frequency of topical initiatives, capacity for regulation, correction and metapragmatic comments (e.g., say it in baby talk), and sociolinguistic skills (i.e., the ability to choose a linguistic style appropriate to the social circumstances of the speech event). Extended discourse skills comprise structural development (genre features); enrichment of linguistic means (textual fabric, used to structure the text); conversational autonomy (free from conversational scaffold from interlocutors); textual autonomy (ability to correctly assess the state of knowledge of the interlocutor so that information in text does not assume shared knowledge); and expansion of range of interest, among others.

From a theoretical standpoint, we could envision many of these early skills as foundational abilities or rudimentary precursors for later, more sophisticated academic-language skills.

Research on metadiscourse (Hyland \& Tse, 2004) also provides an interesting taxonomy of markers that might prove relevant for the study of younger students' oral and written academic language. Whether these metadiscourse elements will be sensitive to developmental changes, in addition to being sensitive to different functions of texts, is an open question that deserves further investigation. Research on the applicability of this taxonomy for pedagogical purposes is another potentially fruitful enterprise. Further research looking at these potential associations would be illuminating, both to construct a comprehensive theoretical model and to inform the design of coherent educational programs.

\section{What Is the Role of Metapragmatic Awareness?}

In line with the conceptualization of academic language presented in Figure 7.2, we urge research attention to the question of whether sociolinguistic and stylistic awareness plays a pivotal role in the development of academic language. We might hypothesize that sociolinguistic awareness is a pre- requisite to mastering academic language. Systematic linguistic variation can be dialectal, sociolectal, ethnic, or gender-based, as well as determined by genre, register, and modality (Ravid \& Tolchinsky, 2002). The ability to switch appropriately across language varieties and registers depends on the opportunities to participate in various communicative situations (Hymes, 1974). Whereas most speakers can at least partially adapt their language forms to specific contexts, expanding these adaptation skills so that students learn how to map language forms onto a variety of situations in a conscious and reflective way may be a crucial step in fostering academic-language proficiency. Moreover, stylistic awareness that is, being aware of a set of linguistic options that have the potential to realize a variety of alternative meanings - may also be necessary. Schleppegrell's research connects particular language forms with specific expectations in illuminating ways. For instance, she documents how the authoritative stance typical of academic discourse is constructed through impersonal subjects, declarative mood structure, and lexical realization of meanings; and she relates lexical density and nominalization to the function of incorporating more (ideational) content into each clause (Schleppegrell, 2001).

\section{What Is the Effect of Mode?}

Academic language is understood as a construct that goes beyond modes of expression and disciplinary boundaries. Bailey (2007) argues for a core set of academiclanguage skills that cuts across different disciplines and is complemented with additional discipline-specific skills. Within this conceptualization, it is relevant to study how different modes of expression (written versus oral) and skills in specific disciplinebased genres (a social studies report versus a science-lab report) influence each other. To what extent skills learned in one mode of expression or in one genre transfer to other domains is an important question, with relevant pedagogical implications. 
Whereas nobody would deny a bidirectional influence of spoken and written language, some researchers emphasize one side as the source of more sophisticated skills. Ravid and Tolchinsky's (2002) intriguing model of linguistic literacy proposes a bidirectional influence; however, their model states that basic features (e.g., basic syntax and phonology) are transferred from speaking to writing, whereas sophisticated features originate in writing and, therefore, exposure to and production of written language is the main factor in enriching linguistic literacy. However, some complex features might also transfer from spoken to written language, as Collaborative Reasoning studies demonstrate (Reznitskaya et al., 2001). Reznitskaya and colleagues show that higher levels of argumentation or reasoning can be achieved through the scaffolding of explicit discourse stratagems. To construct a theoretical model that establishes associations or predictive relationships across modes of expression, research needs to assess later language development so that we can begin to understand which skills get transferred under which conditions.

\section{Is Academic Language Truly More Grammatically Complex?}

Findings on syntactic complexity of academic language are not uncontroversial. Whereas many authors have pointed to a higher degree of subordination in academic writing versus colloquial speech, others (Poole \& Field, 1976) have reported more embedding in spoken language. Tolchinsky and Aparici (2000) found a higher degree of embedding in written than spoken narratives in Spanish but more frequent centerembedded relative clauses in subject position in spoken than written expository texts. As pointed out by Ravid and Tolchinsky (2002) and previously emphasized by Biber (1995), language features should be studied taking into account the influence of register, degree of formality, and planning. In the study of academic-language skills, then, the three domains of knowledge identified in Table 7.2 and all contextual factors men- tioned in Table 7.1 should be considered to develop a precise picture of which skills are displayed under which circumstances.

\section{What Is the Normative Developmental Course and the Ultimate Goal?}

Teachers' expectations and students' skills vary not only by grade but also by discipline and specific genres within disciplines. In addition, academic-language skills can progress to reach highly sophisticated levels such as those used in sharing professional knowledge among a community of experts. Within this range of possibilities, what should be considered the ideal developmental endpoint for academic-language development and, just as important, the minimal educational standards for different grades and content areas?

\section{Teaching Academic-Language Skills \\ Which Academic-Language Skills Should Be Instructed?}

Teaching about mechanisms for representing complex information - both as an approach to reading comprehension and as an input to academic writing - could well be helpful in supporting students' development of academic-language skills. Here again, however, the task may be primarily one of expanding the learner's repertoire of useful stratagems for formulating messages because children from their first months of talking understand the challenge of trying to express complex thoughts with limited language skills. Consider the child lexical forms formerly seen as overgeneralizations, such as calling the postman daddy or calling horses cows; most child-language researchers would now argue that these are simply immature attempts to comment on similarities or to refer despite lexical gaps (Gelman, Croft, Fu, Clausner, \& Gottfried, 1998). Their occurrence suggests that even young children can solve the problem of expressing complex ideas, although in ways that may be unconventional and thus often unsuccessful. 
Exposure to talking styles that display features of academic discourse and participation in academic genres is probably essential for mastering academic language. Children who come from families that value the accumulation and display of knowledge for its own sake, who require warrants for claims, and who model and scaffold the organization of extended discourse and sophisticated utterances will probably have a much easier transition into academic language. However, documentation of how some families support their children's academic-language skills is sorely needed.

For school instruction, attention to linguistic form may be a powerful mechanism for improving students' academic-language skills. A traditional grammar approach might be effective, but the value of a discussion about self, audience, purpose, and the appropriate lexical and grammatical means to represent information in specific school tasks should be ascertained. Assuming that teaching grammatical and lexical devices is essential, we agree with a little-cited claim made by Bakhtin (1942) decades ago:

Without constantly considering the stylistic significance of grammatical choices, the instruction of grammar inevitably turns into scholasticism. In practice, however, the instructor very rarely provides any sort of stylistic interpretation of the grammatical forms covered in class. Every grammatical form is at the same time a means of representing reality. Particularly in instances where the speaker or writer may choose between two or more equally grammatically correct syntactic forms, the choice is determined not by grammatical but by representative and expressive effectiveness of these forms. Teaching syntax without providing stylistic elucidation and without attempting to enrich the students' own speech does not help them improve the creativity of their own speech productions (quoted in Bazerman, 2005).

\section{What Are Effective Pedagogical Approaches?}

Research-based pedagogical approaches to teaching academic-language skills within specific disciplines or genres are starting to emerge (Lemke, 1990; Schleppegrell, Achugar, \& Oteiza, 2004). For instance, content-based instruction (CBI) is a pedagogy for English as a Second Language that integrates language and content-area knowledge with the purpose of improving both dimensions within specific disciplines (Schleppegrell \& de Oliveira, forthcoming). These emerging approaches are promising, yet their design and effectiveness are still in need of further study. How to make the linguistic expectations explicit to students, at what level of precision, and how to further develop sociolinguistic and stylistic awareness skills to improve academic-language performance in the classroom are still open research questions.

A related challenge is how to provide instruction without prescription. Many genre-based classroom pedagogies have been critiqued because of their prescriptive and hierarchical nature and the low transferability of skills produced (Fosen, 2000; Kamler, 1994). Developing students' sociolinguistic competence, stylistic awareness, familiarity with linguistic expectations, and command of lexical and grammatical features of specific genres while emphasizing the individual creativity required for an expert mastery of the interplay between form and meaning is a major challenge.

\section{How Do Planning, Revision, and Rewriting Improve the Advancement of Academic-Language Skills?}

In a conceptualization of academic language as a construct that cuts across modes of expression, exploring the effect of editing as a way of fostering acquisition and awareness of academic skills seems promising. Whereas encouraging students to edit their own texts seems to be a successful approach to improving writing skills, little research has explored the effect of rereading and revising on students' learning (Klein \& Olson, 2001). Research suggests that frequent opportunities for authentic writing improve the quality of students' written products (see Klein \& Olson, 2001, for a brief review). Thus, would 
frequent opportunities for editing texts have a positive effect on academic-language performance? If so, would the skills learned transfer from writing to speaking? How much guidance do students need so that editing can effectively improve academiclanguage skills?

\section{How Can Schools Provide Intervention in Academic-Language Skills to Students Who Start Far Behind?}

Children enter school with different linguistic, sociolinguistic, and pragmatic experiences, and not all of them have been exposed to the forms of communication valued at school. Strategies to make children feel comfortable in expressing who they are and what they bring to school should be at the core of any instructional program. At the same time, schools have the moral obligation to provide all children with equal opportunities to participate in the discourse of academics that is a requisite for later academic success. Children's education can be based in their own culture while also providing explicit teaching of the skills required for success in the academic context of schools (Delpit, 1995). Snow, Cancini, Gonzalez, and Shriberg (1989) found that meeting the expectations of a formal academic register, such as definitional discourse, correlated with academic success. Therefore, children who are less skillful in academic language are less likely to succeed at school. How to provide all children - ELLs and also struggling native English speakers - with equal opportunities of mastering academic language in a way that incorporates and values their primary discourses is yet another challenge.

\section{How Can the Role of Language in Self-Presentation Be Taught?}

It is not obvious that all children automatically see language as a form of self-representation. Evidence from children growing up bilingual suggests that they choose the language that is effective for communication (i.e., for formulating a message that is likely to be successful) from a very early age (e.g., Genesee, 2005, 2006; Genesee \& Nicoladis, in press; Taeschner, 1983) but that they become aware of the 'otherness' imposed by speaking a minority language in public only somewhat later. Furthermore, understanding the relationship of a language to an identity is rather different from understanding how features within a language express identity. Certainly, students do identity work through language in adolescence (Eckert, 1989), but it is not clear how much metalinguistic awareness they have about those linguistic decisions. Thus, it is worth exploring whether students might benefit from teaching designed to make the problem of self-representation explicit because that is a source of important academic-language features - but, at the same time, a pragmatic force to which they may be blind. One approach to this task might be sociolinguistic exploration of questions like "How does the language of people in power differ from the language of those in subordinate positions?" Another approach might involve text analysis to determine, for example, which markers readers use to infer the writer's level of certainty or to decide whether they consider the writer trustworthy.

\section{Do Students Need Instruction in Metasociolinguistic Awareness?}

Another somewhat different approach would be taken if we assumed that students knew the importance of linguistically managing self-representation but lacked a full understanding of the cues signaling the appropriate representation for academic settings. In that case, a metasociolinguistic curriculum might be appropriate, one that specified the factors leading to the need for greater care in representing oneself as knowledgeable or trustworthy (see Table 7.1 for a preliminary list of the situations that do/do not call for academic language). How should talking to one's friends in class differ from talking to them on the playground? How does pursuing an intellectual dispute differ from arguing with one's boyfriend? ${ }^{6}$ Charting students' knowledge about these 
issues might be a research undertaking worth pursuing and might shed light on how to gradually bring them to deeper understandings of the interactions between form and meaning.

A related research area involves exploring the best strategy to help students understand the importance of continuing to expand their language knowledge. For example, would it be fruitful to teach teachers and/or students explicitly about the concept of 'academic language'? Should we also teach students about the multidimensionality of language - discussing, for example, how having a conversation with friends requires a different set of skills than a formal presentation? Would this knowledge be helpful and, if so, at what level of specification? Which purposeful activities would best help promote this learning?

\section{In What Informational Context Should Teachers Teach Academic-Language Expression?}

Studying the development of definitional skill, Snow (1990) reported no age differences in the amount of information children provided but significant age differences in "the way they organize that information into the formal structure required" (p. 708). These findings lead us to reflect about whether is it too much to ask of students that they simultaneously learn content and linguistic organization. Should academic language perhaps be taught initially in the context of highly familiar topics or topics for which students have abundant background knowledge?

\section{Which Genres Are the Most Important?}

Which discourse varieties should be included under the label "academic language" for the purposes of improving schoolrelevant linguistic skills? What are the crucial discourse varieties students need to master in school? Should we study mainly the language of the most traditional academic subjects, or should we also include other professional discourses, such as journalistic, legal, medical, or business language? Ravid and Tolchinsky (2002, p. 421) note that discourse varieties "can be thought of as multidimensional spaces within which speakers and writers move, and which can be defined at different depths of focus: for example,... the genre of a high school physics textbook versus the less specific genre of natural sciences." What should be the depth of focus in defining academic registers? In other words, should we focus on highly specific genres, such as a laboratory report, a project proposal, and a biography, or should we direct our efforts to clusters of genres that share register features, such as scientific versus persuasive discourse?

\section{Conclusion}

We have suggested several possible lines of research focused on understanding the origins of academic-language skill, probing the differential success of different groups of students with it and evaluating different approaches to helping all students master it. The basic question underlying all of these suggestions is one about the source of the challenge: academic language, like all linguistic communication, involves challenges at the level of self-representation, representing a message, constructing discourse, and composing utterances. Where in this nested process do students encounter particular difficulties, and are those difficulties primarily ones of understanding or of performing the task? If we had the answer to these questions, then we would be well on our way to devising effective instruction for students and professional development for teachers to ensure universal improvement in this crucial aspect of academic functioning.

\section{Notes}

1 The authors' names are in alphabetical order. The authors would like to thank The Spencer Foundation, which has supported the first author's work on this topic, and the Institute of Education Sciences, which has supported the second author through the grants 
"Diagnostic Assessment of Reading Comprehension: Development and Validation" and "Improving Reading Comprehension for Struggling Readers."

2 Register is a central notion in SFL. Register is defined as "the constellation of lexical and grammatical features that characterizes particular uses of language" (Halliday \& Hassan, 1989). As elaborated by Schleppegrell (2001, pp. 431-432): "A register reflects the context of a text's production and at the same time enables the text to realize that context. In other words, the grammatical choices are made on the basis of the speaker's perception of the social context, and those choices then also serve to instantiate that social context.... Registers manifest themselves both in choice of words or phrases and also in the way that clauses are constructed and linked." Each genre has its own register features and different genres can share many common register features. Genres are purposeful, staged uses of language that are accomplished in particular cultural contexts (Christie, 1985, as quoted in Schleppegrell, 2001). As stated by Schleppegrell, certain lexical and grammatical features are common to many school genres because they are functional for "doing schooling" (Schleppegrell, 2001, p. 432).

3 This table is organized in categories imposed by the authors of this chapter.

4 Note that we are not arguing here that academic language is more complex overall than other forms of language. Language forms constitute adequate responses to a variety of communicative challenges; thus, complexity can be manifested at different levels in various language exchanges. We are simply highlighting one specific dimension of complexity. More colloquial forms can be more complex in other dimensions - for example, in how linkages among clauses are indicated from one part of a discourse to another (Schleppegrell, 2001).

5 For example, a paper submitted to a special issue of Hormones and Behavior that reviewed how the functioning of pheromones as social cues is mediated by brain structures included the sentence, "We thus conclude there is something funky going on in the amygdala."

6 It is worth noting that in one fifth-grade classroom that implemented the Word Generation curriculum, the teacher often closed down the heated student debates on the topic of the week by saying "but we are still going to be friends, right?," thus explicitly marking the distinction between the academic arguments and the normal classroom relationships.

\section{References}

Achugar, M., \& Schleppegrell, M. J. (2005). Beyond connectors: The construction of cause in history textbooks. Linguistics and Education, 16 (3), 298-318.

August, D., \& Shanahan, T. (2006). Developing literacy in second-language learners: Report of the national literacy panel on language minority children and youth. Mahwah, NJ: Lawrence Erlbaum; Washington, DC: Center for Applied Linguistics.

Bailey, A. (2007). The language demands of school: Putting academic English to the test. New Haven, CT: Yale University Press.

Bailey, A. (in press). From Lambie to Lambaste: The conceptualization, operationalization, and use of academic language in the assessment of ELL students. In K. Rolstad (Ed.), Rethinking school language. Mahwah, NJ: Lawrence Erlbaum Associates.

Bazerman, C. (2005). An essay on pedagogy by Mikhail M. Bakhtin. Written Communication, 22 (3), 333-338.

Berman, R. A. (2004). The role of context in developing narrative abilities. In S. Strömqvist \& L. Verhoeven, (Eds.), Relating events in narrative: Typological and contextual perspectives. Mahwah, NJ: Lawrence Erlbaum, 261280.

Bhatia, V. J. (2002). Applied genre analysis: Analytical advances and pedagogical procedures. In A. M. Johns (Ed.), Genre in the classroom: Multiple perspectives. Mahwah, NJ: Lawrence Erlbaum Associates.

Biber, D. (1995). Dimensions of register variation: A cross-linguistic comparison. Cambridge: Cambridge University Press.

Biber, D., \& Reppen, R. (2002). What does frequency have to do with grammar teaching? Studies in Second Language Acquisition, 24 (2), 199-208.

Blum-Kulka, S. (in press). Language, communication and literacy: Steps in the development of literate discourse. In P. Klein \& K. Yablon (Eds.), Modes of early education and their effect on improving education in school. The Initiative for Applied Research in Education, Israeli Academy of Science.

Chafe, W., \& Danielewicz, J. M. (1987). Properties of spoken and written language. In 
R. Horowitz \& S. J. Samuels (Eds.), Comprehending oral and written language (pp. 83-113). San Diego, CA: Academic Press.

Chamot, A. U., \& O'Malley, J. M. (1994). The CALLA handbook: Implementing the cognitive academic language learning approach. Reading, MA: Addison-Wesley.

Colombi, M. C. (2002). Academic language development in Latino students' writing in Spanish. In M. J. Schleppegrell \& M. C. Colombi (Eds.), Developing advanced literacy in first and second languages: Meaning with power, 67-86. Mahwah, NJ: Lawrence Erlbaum Associates.

Colombi, M. C., \& Schleppegrell, M. J. (2002). Theory and practice in the development of advanced literacy. In M. J. Schleppegrell \& M. C. Colombi (Eds.), Developing advanced literacy in first and second languages: Meaning with power (pp. 1-20). Mahwah, NJ: Lawrence Erlbaum Associates.

Cummins, J. (1980). The cross-lingual dimensions of language proficiency: Implications for bilingual education and the optimal age issue. TESOL Quarterly, 14, 175-187.

Cummins, J. (1981). Age on arrival and immigrant second-language learning in Canada: A reassessment. Applied Linguistics, 2, $132-$ 149.

Cummins, J. (1984). Language proficiency and academic achievement revisited: A response. In C. Rivera (Ed.), Language proficiency and academic achievement. Clevedon, UK: Multilingual Matters.

Cummins, J. (2001). Negotiating identities: Education for empowerment in a diverse society. 2nd Edition. Los Angeles: California Association for Bilingual Education.

Delpit, L. (1995). Other people's children: Cultural conflict in the classroom. New York: The New Press.

Eckert, P. (1989). Jocks and burnouts: Social categories and identity in the high school. New York: Teachers College Press.

Fosen, C. (2000). Genres made real: Genre theory as pedagogy, method, and content. Paper presented at the Annual Meeting of the Conference on Composition and Communication, Minneapolis, MN.

Gelman, S., Croft, W., Fu, P., Clausner, T., \& Gottfried, G. (1998). Why is a pomegranate an apple? The role of shape, taxonomic relatedness, and prior lexical knowledge in children's overextensions of apple and dog. Journal of Child Language, 25, 267-291.
Genesee, F. (2005). The capacity of the language faculty: Contributions from studies of simultaneous bilingual acquisition. In J. Cohen, K. T. McAlister, K. Rolstad, \& J. MacSwan (Eds.), Proceedings of the $4^{\text {th }}$ International Symposium on Bilingualism (pp. 89o901). Somerville, MA: Cascadilla Press.

Genesee, F. (2006). Bilingual first language acquisition in perspective. In E. Hoff \& P. McCardle (Eds.), Childhood bilingualism (pp. 45-67). Clevedon, UK: Multilingual Matters.

Genesee, F., \& Nicoladis, E. (in press). Bilingual acquisition. In E. Hoff \& M. Shatz (Eds.), Handbook of language development, Oxford: Blackwell.

Halliday, M. A. K. (1987). Spoken and written modes of meaning. In R. Horowitz \& S. J. Samuels (Eds.), Comprehending oral and written language (pp. 55-82). San Diego, CA: Academic Press.

Halliday, M. A. K. (1993). Some grammatical problems in scientific English. In M. A. K. Halliday \& Martin, J. R., Writing science: Literacy and discursive power. London: Falmer (Critical Perspectives on Literacy and Education); Pittsburgh: University of Pittsburgh Press. (Pittsburgh Series in Composition, Literacy, and Culture).

Halliday, M. A. K. (1994a). A language development approach to education. In N. Bird, et al. (Eds.), Language and learning. Papers presented at the Annual International language in Education Conference, Hong Kong, 1993.

Halliday, M. A. K. (1994b). An introduction to functional grammar. London: Edward Arnold.

Halliday, M. A. K., \& Martin, J. R. (1993). Writing science: Literacy and discursive power. London: Falmer (Critical Perspectives on Literacy and Education); Pittsburgh: University of Pittsburgh Press. (Pittsburgh Series in Composition, Literacy, and Culture).

Hemphill, L. (1989). Topic development, syntax, and social class. Discourse Processes, 12 (3), 267286.

Hyland, K., \& Tse, P. (2004). Metadiscourse in academic writing: A reappraisal. Applied Linguistics, 25 (2), 156-177.

Hymes, D. (1974). Foundations in sociolinguistics: An ethnographic approach. Philadelphia: University of Pennsylvania Press.

Kamler, B. (1994). Gender and genre in early writing. Linguistics and Education, 6 (2), 153-182.

Kieffer, M., Lesaux, N., \& Snow, C. E. (in press). Promises and pitfalls: Implications of 
No Child Left Behind for defining, assessing, and serving English language learners. In G. Sunderman (Ed.), Holding NCLB accountable: Achieving accountability, equity, and school reform. Thousand Oaks, CA: Corwin Press.

Klein, P. D., \& Olson, D. R. (2001). Texts, technology, and thinking: Lessons from the Great Divide. Language Arts, 78 (3), 227-236.

Lemke, J. L. (1990). Talking science: Language, learning, and values. Norwood, NJ: Ablex Publishing.

Michaels, S., \& O'Connor, M. C. (2002). Accountable talk: Classroom conversation that works [CD-ROM]. Pittsburgh, PA: University of Pittsburgh.

Ong, W. J. (1982/1995). Orality and literacy: The technologizing of the world. London/New York: Routledge Press.

Pilgreen, J. (2006). Supporting English learners: Developing academic language in the content area classroom. In A. Terrel \& N. L. Hadaway (Eds.), Supporting the literacy development of English learners. Newark, DE: International Reading Association.

Poole, M. E., \& Field, T. W. (1976). A comparison of oral and written code elaboration. Language and Speech, 19, 305-311.

Ravid, D., \& Tolchinsky, L. (2002). Developing linguistic literacy: A comprehensive model. Journal of Child Language, 29 (2), 417-447.

Reznitskaya, A., Anderson, R., Nurlen, B., Nguyen-Jahiel, K., Archodidou, A., \& Kim, $\mathrm{S}$. (2001). Influence of oral discussion on written argument. Discourse Processes, 32, 155175 .

Scarcella, R. (2003). Academic English: A conceptual framework. The University of California Linguistic Minority Research Institute. Technical Report 2003-1.

Schleppegrell, M. J. (2001). Linguistic features of the language of schooling. Linguistics and Education, 14 (4), 431-459.

Schleppegrell, M. J. (2007). The linguistic challenges of mathematics teaching and learning: A research review. Reading \& Writing Quarterly: Overcoming Learning Difficulties, 23 (2), 139-159.
Schleppegrell, M. J., Achugar, M., \& Oteiza, T. (2004). The grammar of history: Enhancing content-based instruction through a functional focus on language. In TESOL Quarterly: A Journal for Teachers of English to Speakers of Other Languages and of Standard English as a Second Dialect, 38, 67-93.

Schleppegrell, M. J., \& Colombi, M. C. (2002). Developing advanced literacy in first and second languages: Meaning with power (pp. 1-20). Mahwah, NJ: Lawrence Erlbaum Associates.

Schleppegrell, M. J., \& de Oliveira, L. C. (forthcoming). An integrated language and content approach for history teachers. Journal of English for Academic Purposes.

Snow, C. E. (1990). The development of definitional skill. Journal of Child Language, 17, 697-710.

Snow, C. E., Cancini, H., Gonzalez, P., \& Shriberg, E. (1989). Giving formal definitions: An oral language correlate of school literacy. In D. Bloome (Ed.), Classrooms and literacy (pp. 233-249). Norwood, NJ: Ablex.

Spolsky, B., \& Hult, F. M. (2007). Handbook of educational linguistics. Oxford: Blackwell Publishing.

Swales, J. (1990). Genre analysis: English in academic and research settings. Cambride: Cambridge University Press.

Taeschner, T. (1983). The sun is feminine: A study on language acquisition in bilingual children. Berlin: Springer-Verlag.

Tolchinsky, L. \& Aparici, M. (2000). Is written language more complex than spoken language? International literacy project working papers in developing literacy across genres, modalities, and languages, Vol. III. Barcelona: Institute of Educational Sciences.

Wignell, P., Martin, J. R., \& Eggins, S. (1993). The discourse of geography: Ordering and explaining the experiential world. In M. A. K. Halliday \& J. R. Martin (Eds.), Writing science: Literacy and discursive power (pp. 136-165). London: Falmer (Critical Perspectives on Literacy and Education); Pittsburgh: University of Pittsburgh Press (Pittsburgh Series in Composition, Literacy, and Culture). 